GRASAS Y ACEITES 70 (3)

July-September 2019, e314

ISSN-L: 0017-3495

https://doi.org/10.3989/gya.0818182

\title{
Characterization of lignocellulosic composition and residual lipids in empty fruit bunches from palm oil processing
}

\author{
M.P.C. Volpi ${ }^{\mathrm{a}}$, R.G. Bastos ${ }^{\mathrm{b}}$, A.P.R. Badan ${ }^{\mathrm{c}}$, M.H.A. Santana ${ }^{\mathrm{a}}$ and V.S. Santos ${ }^{\mathrm{a}, \bigotimes}$ \\ ${ }^{\mathrm{a}}$ Department of Engineering of Materials and Bioprocesses, School of Chemical Engineering, \\ University of Campinas, Albert Einstein Avenue, 500, Campinas - SP, 13083-852. \\ ${ }^{b}$ Department of Agroindustrial Technology and Rural Socioeconomics, Federal University of São Carlos (Ufscar), \\ Araras Campus, Anhanguera Highway, Km 174 - Zona Rural, Araras - SP, 13604-900. \\ ${ }^{c}$ Department of Food Technology, School of Food Engineering, University of Campinas, \\ Rua Monteiro Lobato, 80, Campinas-SP, 13083-862. \\ Corresponding author: santosilvaleria@hotmail.com
}

Submitted: 02 August 2018; Accepted: 03 December 2018. Published online: 30 April 2019

\begin{abstract}
SUMMARY: Empty fruit bunches (EFBs) are an agro-industrial residue discarded in the environment when the fresh palm fruits are removed for oil extraction. EFBs are abundant in palm-oil-producing countries and cause environmental problems. Besides their content in lignocellulosic, EFBs also contain amounts of residual lipids from the separation process. Because the palm fruit has two main types of oil from the pulp (palm oil) or the seeds (kernal oil), the residual EFBs lipids may have different compositions. Thus, this work aimed at characterizing the lignocellulosic content and the residual lipids in two EFBs from different palm oil producers. The EFBs were classified as Type 1 and Type 2 according to their source. The results showed that Type 1 EFBs had higher lignocellulosic and fatty acid compositions, similar to palm and kernel oils, while Type 2 EFBs had lower lignocellulosic content and fatty acid composition, similar to palm oil.
\end{abstract}

KEYWORDS: Agro-industrial residue; Empty Fruit Bunches; Lignocellulosic material; Lipids; Palm oil

RESUMEN: Caracterización de la composición lignocelulósica y lípidos residuales en racimos de frutos vacíos del procesado de aceite de palma. Los racimos de fruta vacíos (EFBs, por sus siglas en inglés) son un residuo agroindustrial que se desecha cuando se extraen las frutas frescas de palma para extraer el aceite. Los EFBs abundan en los países productores de aceite de palma, lo que genera problemas ambientales. Además de su contenido lignocelulósicos, EFBs también contiene una cantidad de lípidos residuales del proceso de separación. Debido a que la fruta de la palma tiene dos tipos principales de aceite, los de la pulpa (aceite de palma) o de las semillas (aceite de grano), los lípidos residuales de EFBs pueden tener diferentes composiciones. Por lo tanto, este trabajo tuvo como objetivo caracterizar el contenido lignocelulósico y los lípidos residuales en EFBs de diferentes productores de aceite de palma. Los EFBs se clasificaron como Tipo 1 y Tipo 2 según su fuente. Los resultados mostraron que el EFBs tipo 1 tenía una mayor composición lignocelulósica y de ácidos grasos similar a los aceites de palma y de grano, mientras que el EFBs tipo 2 tenía un contenido lignocelulósico inferior y una composición de ácidos grasos similar al aceite de palma.

PALABRAS CLAVE: Aceite de palma; Lípidos; Manojo de frutas vacias; Material lignocelulósico; Residuo agroindustrial

ORCID ID: Volpi MPC https://orcid.org/0000-0003-0498-269X, Bastos RG https://orcid.org/0000-0003-0733-4137, Badan APR https://orcid.org/0000-0002-6532-1265, Santana MHA https://orcid.org/0000-0002-2258-4911, Santos VS https://orcid.org/0000-0002-0912-462X

Citation/Cómo citar este artículo: Volpi MPC, Bastos RG, Badan APR, Santana MHA, Santos VS. 2019. Characterization of lignocellulosic composition and residual lipids in empty fruit bunches from palm oil processing. Grasas Aceites 70 (3), e314. https://doi.org/10.3989/gya.0818182

Copyright: (02019 CSIC. This is an open-access article distributed under the terms of the Creative Commons Attribution 4.0 International (CC BY 4.0) License. 


\section{INTRODUCTION}

The palm oil industry is one of the largest oil producers in the world. The oleaginous palm (Elaeis guineensis Jacq.), belonging to the Arecaceae family, originated in West Africa, Indonesia, Malaysia and Thailand, and also in Brazil (Alves et al., 2011). In 2015, the Directorate of Processing and Marketing of Agricultural Products of the Indonesian Ministry of Agriculture reported the total palm plantation to reach 11.4 million hectar; and to produce approximately 20-24 tons of palm oil /hectar (Pujiasih et al., 2018).

The main residue from palm oil processing is the empty fruit bunches (EFBs), which are discarded into the environment after removal of the fresh fruits used for the extraction of palm oil. The amount of EFBs is much greater than other residue such as the kernel shells and mesocarp fibers (Yeoh et al., 2011, Chang, 2014).

EFBs are classified as a lignocellulosic residue, composed on average of $44.4 \%$ cellulose, $30.9 \%$ hemicellulose and $14.2 \%$ lignin. The high concentration of cellulose and low lignin add value to the product (Ferrer et al., 2012; Nazir et al., 2013).

The oil extraction process initially involves the collection of fresh bunches in plantations and transportation to the extraction unit where they are treated by steam, followed by passing through a threshing machine to separate the fresh fruits and the empty bunches (Bocchi, 2008). In the separation process, a residual oil may remain in EFBs. According to Hoffman, as cited by Gioielli (1996), the extraction process of palm oil fruit may occur by solvent, when the oil content in the fruits is less than $25 \%$, or by pressing for the highest concentrations. Two types of oil are extracted from the fruits: the palm oil from the pulp or mesocarp and the palm kernel oil from the seeds. The fatty acid composition of these oils is completely different. In palm oil, the predominant fatty acids are palmitic and oleic acids, while palm kernel oil, similar to coconut and babassu coconut, primarily contains lauric, myristic and oleic fatty acids (Block, Barrera-Arellano, 2013).

In terms of stability, palm oil is one of the most resistant vegetable oil to oxidation due to the presence of natural antioxidants. It is in a semi-solid state at room temperature because of its composition of fatty acids $(50 \%$ saturated, $40 \%$ monounsaturated and 10\% polyunsaturated) (Anton, Bailey, 2005).

The average composition of the fatty acids in palm kernel oil is $48 \%$ lauric acid, $16 \%$ myristic acid and $15 \%$ oleic acid. They have a high fusion point because of the preponderance of saturated fatty acids combined with low levels of unsaturation and are solid at room temperature (Anton, Bailey, 2005).
In addition, the literature reports that the fibers of the palm fruit mesocarp contain bioactive compounds such as carotenoids, tocopherols and phytosterols (Cardenas-Toro et al., 2015; Lau et al., 2008).

Studies have shown the potential of EFBs for use in some areas such as paper making and fabrication of reinforced materials (Hurter, Byrd, 2017; Rosazley et al., 2016). Motta and Santana (2014) showed the capacity of EFBs to produce humic acids through submerged fermentation and solid-state fermentation, using the fungus of Trichoderma genus. In addition, it is possible to extract carotenoids from the palm fruit mesocarp (Cardenas-Toro et al., 2015).

Thus, the aim of this research was to characterize the lignocellulosic content and the residual lipids present in EFBs from different palm oil producers. The results are useful for secondary recovery of the oil, as well as for the development of novel technologies.

\section{MATERIALS AND METHODS}

\subsection{Materials}

Two types of EFBs were used, Type 1 - provided by an industrial process of the Agropalma ${ }^{\circledR}$ industry, Limeira, São Paulo, Brazil, and Type 2 - from craft processes of the cooperative of small palm oil producing industries (Muniz Ferreira, Bahia, Brazil).

\subsection{Methods}

\subsubsection{Moisture and lignocellulose characterization of EFBs}

EFBs samples were stored at $5{ }^{\circ} \mathrm{C}$ and characterized by moisture content according to Approved Methods of the American Association of Cereal Chemists (AACC) 44-15.02 (AACCI, 2010). The quantification of cellulose, hemicellulose and lignin was performed using neutral detergent fiber (NDF) and acid detergent fiber (ADF) according to the Association of Official Analytical Chemists (AOAC, 2016).

\subsubsection{Extraction of lipids from EFBs}

The residual lipids were extracted from EFBs fibers for characterization and quantification. Extraction was carried out in a Soxhlet Extractor using petroleum ether according to the American Oil Chemists' Society (AOCS) method AM 2-93 (AOCS, 2009).

\subsubsection{Characterization of residual lipids from EFBS}

Free fatty acid composition. Free fatty acids were determined by the Ca 5a-40 AOCS method (AOCS, 2009). The analyses were performed after 
esterification on a capillary gas chromatography (CGC Agilent 6850 Series GC System) according to the method of Hartman and Lago (1973). The methyl esters of the fatty acids were separated according to the procedure of AOCS Ce 1f-96 (AOCS, 2009) on an Agilent DB-23 capillary column (50\% Cyanopropyl-methylpolysiloxane) with the following dimensions: $6.0 \mathrm{~m} \times 0.25 \mathrm{~mm} \times 0.25 \mathrm{~m}$. The operating conditions of the chromatograph were as follows: column flow rate $=1.0 \mathrm{~mL} \cdot \mathrm{min}^{-1}$; linear velocity $=24 \mathrm{~cm} \cdot \mathrm{s}^{-1}$; detector temperature $=280^{\circ} \mathrm{C}$; injector temperature $=250{ }^{\circ} \mathrm{C}$; oven temperature $=$ $110-215^{\circ} \mathrm{C}\left(5^{\circ} \mathrm{C} \cdot \mathrm{min}^{-1}\right), 215^{\circ} \mathrm{C}$ for $24 \mathrm{~min}$; drag gas - helium; and volume of injection $=1.0 \mu \mathrm{L}$.

Iodine and peroxide indices. The iodine indices were determined from the composition of fatty acids by the methodology of AOCS Cd 1c-85 (AOCS, 2009). The peroxide index was obtained by the method $\mathrm{Cd}$ 8b-90 (AOCS, 2009) based on titration with $0.1 \mathrm{M}$ sodium thiosulphate and the use of a starch solution as indicator.

Lipid classes. The lipid classes were determined by size exclusion chromatography (HPSEC) on a Perkin Elmer liquid chromatograph 250; Sicon Analytic refractive index detector; Column 1: Jordi Gel dvb $300 \times 7.8$ mm, $500 \AA$ Å; Column 2: Jordi Gel dvb $300 \times 7.8 \mathrm{~mm}, 100 \AA$. Conditions: mobile phase:

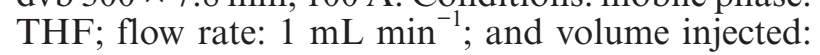
$20.0 \mu \mathrm{L}$ of $20 \mathrm{mg} / \mathrm{mL}$ THF diluted sample.

Triacylglycerol composition. The triacylglycerol (TAG) composition was analyzed after the TAG fraction was isolated from diacylglycerols (DAG), monoacylglycerols (MAG) and free fatty acids (FFA). The samples were purified by passing the oil through a silica SPE column, according to Moreda et al. (2003). Briefly, the column was placed in a vacuum elution apparatus and washed with $6.0 \mathrm{~mL}$ hexane under atmospheric pressure. The lipid matrix $(0.12 \mathrm{~g})$ was diluted in $0.5 \mathrm{~mL}$ hexane and loaded into the column. The solution was pulled through and then eluted with $10.0 \mathrm{ml}$ hexane-diethylether (87:13 v:v) under atmospheric pressure. The eluted solution was then evaporated to dryness in a rotary evaporator under reduced pressure at room temperature. The residue was split into two parts for the TAG and fatty acid composition determinations. TAG compositions were analyzed according to the method AOCS Ce 5-86 (AOCS, 2009) in a capillary gas chromatography (CGC Agilent 6850 Series Gc System). The capillary column used was the DB-17 HT Agilent Catalog: 122-1811 (50\% phenylmethylpolysiloxane) with dimensions of $15.0 \mathrm{~m}, \varnothing$ int: $0.25 \mathrm{~mm}$ and $0.15-\mu \mathrm{m}$ film. The operating conditions of the chromatograph were as follows: flow column $=1.0 \mathrm{~mL} \cdot \mathrm{min}^{-1}$; linear speed $=40 \mathrm{~cm} \cdot \mathrm{sec}^{-1}$; detector temperature: $375^{\circ} \mathrm{C}$; injector temperature:
$360{ }^{\circ} \mathrm{C}$; oven temperature: $280-340{ }^{\circ} \mathrm{C}\left(2^{\circ} \mathrm{C} \cdot \mathrm{min}^{-1}\right)$, $340{ }^{\circ} \mathrm{C}-40$ minutes; drag gas: helium; injected volume: $1.0 \mu \mathrm{L}$, split 1:100; and sample concentration: $10.0 \mathrm{mg} \cdot \mathrm{mL}^{-1}$ tetrahydrofuran. The fatty acid composition from the TAG fraction was determined according to IUPAC Standard Methods (IUPAC, 1987) as the composition of fatty acid methyl esters (FAME) by GC. Trans-esterification of the oil was carried out with $\mathrm{KOH}$ in methanol at a concentration of $2.0 \mathrm{~mol} \cdot \mathrm{L}^{-1}$. For FAME separation, the chromatographic conditions described above were used.

Phytosterol composition. To determine the phytosterol composition, the unsaponifiable matter was initially extracted by the AOCS Ca $6 \mathrm{a}-40$ method (AOCS, 2009). The sterol profile in the samples was obtained according to the Ch 6-91 method, and the total sterol content was quantified using of an internal standard a-cholestanol (Sigma-Aldrich).

Carotenoid content. The total carotenoid content was obtained using the method described by Porim (1995). Briefly, the samples $(0.8 \mathrm{~g})$ were diluted in hexane $(25.0 \mathrm{~mL})$, and the absorbance was read in a spectrophotometer at $466 \mathrm{~nm}$ (UV / VIS Lambda 20 - Perkin Elmer).

Tocopherol composition. Tocopherols were determined according to the IUPAC Standard Method 2432 (IUPAC, 1987). Oil samples were diluted in hexane $\left(10.0 \mathrm{mg} \cdot \mathrm{mL}^{-1}\right)$, followed by injection directly into the liquid phase chromatography system equipped with a Si column $(250 \mathrm{~mm} \times 4.0 \mathrm{~mm} \times 4 \mu \mathrm{m})$ and a fluorescence detector (Shimadzu RF-10AXL fluorescence detector) adjusted to excitation and emission at wavelengths of 290 and $330 \mathrm{~nm}$, respectively. A hexane:2-propanol mixture $(99: 1, v: v)$ at a flow rate of $1.0 \mathrm{~mL} \cdot \mathrm{min}^{-1}$ was used as a diluent. Tocopherol concentrations $\left(\mathrm{mg} \cdot \mathrm{kg}^{-1}\right)$ were determined from a calibration curve using tocopherol standards in hexane in the range of 4 to $6 \mu \mathrm{g} \cdot \mathrm{mL}^{-1}$.

\section{RESULTS AND DISCUSSION}

\subsection{Lignocellulosic characterization of EFBs}

Table 1 shows the lignocellulosic characterization, expressed in cellulose, hemicellulose and lignin of the two EFB Types.

Although similar proportions exist among the components, the lignocellulosic content was higher in Type 1 EFBs. Motta and Santana (2014) found in their studies with EFBs proportions of $12 \%$ lignin, $27 \%$ cellulose and 39\% hemicellulose. Therefore, it is possible to affirm that the values found in the present study were within the range presented in the literature, emphasizing that the variation in the lignocellulosic composition often depends on the soil and the region the EFBs come from. Figure 1 shows 
TABLE 1. Lignocellulosic composition of the EFBs

\begin{tabular}{lcccc}
\hline EFBs* & $\begin{array}{c}\text { Cellulose (C) } \\
(\%)\end{array}$ & $\begin{array}{c}\text { Hemicellulose (H) } \\
\text { (\%) }\end{array}$ & $\begin{array}{c}\text { Lignin (L) } \\
\mathbf{( \% )}\end{array}$ & $\begin{array}{c}\text { Proportion } \\
\text { C:H:L }\end{array}$ \\
\hline Type 1 & 31.9 & 19.8 & 24.1 & $1.3: 0.8: 1$ \\
Type 2 & 17.9 & 15.2 & 13.7 & $1.3: 1.1: 1$ \\
\hline
\end{tabular}

*Type 1 (the higher lignocellulosic content and fatty acid composition of this oil was similar to a mixture of palm oil and palm kernel) and Type 2 (the lower lignocellulosic content and fatty acid composition of this oil was similar to palm oil).

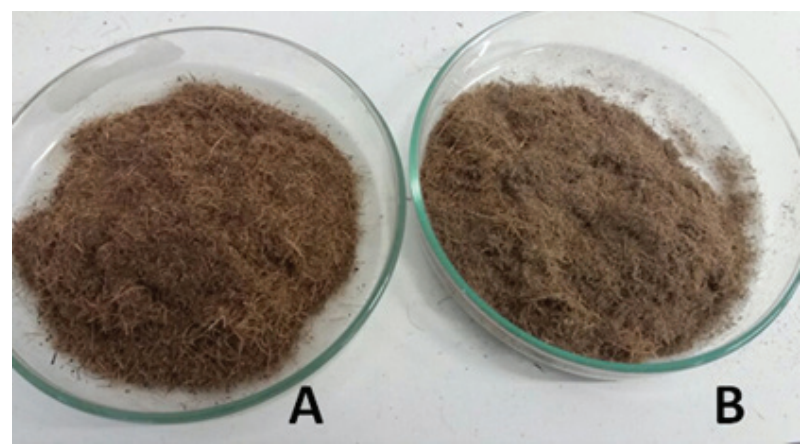

Figure 1. Visualization of Type $1(\mathrm{~A})$ and Type 2 (B) EFBs after lipid extraction.

the visualization of the EFBs after extraction of the residual lipids. The darker color in Type 1 EFBs corresponds to the higher lignocellulosic concentration. The moisture content in the EFBs was $11.5 \%$ (Type 1) and $18.9 \%$ (Type 2).

\subsection{Characterization of residual lipids in EFBs}

The residual lipid contents were $6.9 \%$ in Type 1 EFBs and $38.4 \%$ in Type 2 EFBs in the relation of one kilogram of each EFBs. The compositions of residual fatty acids in the EFBs are presented in Table 2.

The data show that Type 2 EFBs present a higher concentration of saturated fatty acids $(76.5 \%)$ compared with Type 1 EFBs $(52.0 \%)$. The percentage of saturated lipids in Type 2 EFBs is predominantly composed of palmitic $(\sim 66 \%)$ and stearic fatty acids $(\sim 8 \%)$, followed by smaller amounts of myristic and arachidonic acids. In Type 1 EFBs, the predominant saturated fatty acids were palmitic acid $(\sim 32 \%)$, lauric acid $(\sim 9 \%)$, stearic acid $(\sim 4 \%)$ and myristic acid $(\sim 4 \%)$ as well as $\sim 1 \%$ short-chain fatty acids such as caprylic acid and capric acid.

The unsaturated fractions correspond to the oleic and linoleic fatty acids in the residues, adding a total of $21.8 \%$ in the lipid content of Type 2 EFBs and $46.4 \%$ in Type 1 EFBs.

The iodine value refers to the active sites of unsaturation in the fatty acids that compose the oils. According to Santos (2014), the calculation of the
TABLE 2. Fatty acid composition in EFBs

\begin{tabular}{lcc}
\hline Fatty Acids & $\begin{array}{c}\text { Type 1 } \\
\mathbf{E F B s}^{\mathbf{a}} \mathbf{( \% )}\end{array}$ & $\begin{array}{c}\text { Type 2 } \\
\mathbf{E F B s}^{\mathbf{a}} \mathbf{( \% )}\end{array}$ \\
\hline C8:0 - Caprylic Acid & $0.7 \pm 0.1$ & -- \\
C10:0 - Capric Acid & $0.7 \pm 0.1$ & -- \\
C12:0 - Lauric Acid & $9.5 \pm 0.5$ & -- \\
C14:0 - Myristic Acid & $3.9 \pm 0.1$ & $1.4 \pm 0.1$ \\
C16:0 - Palmitic Acid & $32.5 \pm 1.6$ & $65.9 \pm 4.0$ \\
C18:0 - Stearic Acid & $4.4 \pm 0.2$ & $8.4 \pm 0.1$ \\
C18:1 - Oleic Acid & $37.6 \pm 2.3$ & $20.9 \pm 2.6$ \\
C18:2 - Linoleic Acid & $8.7 \pm 0.5$ & $0.8 \pm 0.8$ \\
C18:3 - Linolenic Acid & -- & -- \\
C20:0 - Arachidonic Acid & -- & $0.6 \pm 0.1$ \\
E Saturated & 52.0 & 76.5 \\
E Unsaturated & 46.4 & 21.8 \\
I V & 110.2 & 82.1 \\
FFA (\%) & $9.3 \pm 0.1$ & $51.6 \pm 1.1$ \\
PV & $12.4 \pm 1.2$ & $67.5 \pm 3.0$ \\
\hline
\end{tabular}

${ }^{\mathrm{a}}$ Mean of three replicates \pm standard deviation; Values below $0.5 \%$ were omitted from the table. --: not detected; IV: iodine value, PV: peroxide value, FFA: free fatty acids

iodine content, obtained from the composition in fatty acids, provided a value for palm oil of 52.7, indicating high levels of unsaturation. In Table 2, the iodine value in Type 1 EFBs was higher than in Type 2, confirming that the first has more instaurations, and is more susceptible to oxidation.

The differentiated chemical composition between saturated and unsaturated fatty acids gives the differentiated physical properties of the lipids. It was observed that Type 2 EFBs was solid at room temperature and therefore can be considered a fat, while Type 1 EFBs remained liquid under the same conditions and can be considered an oil according to the basic classification of oils and fats (Block and Barrera-Arellano, 2013).

Palm oil has equilibrium in saturated and unsaturated fatty acids, and is semi-solid at room temperature since it consists of approximately $50 \%$ saturated fatty acids and 50\% unsaturated fatty acids (Rukmini, 1994). According to Block and Barrera-Arellano (2009), the saturated fatty acids present in palm oil are between $42-40 \%$ palmitic acid, $4-5 \%$ stearic acid, $39-40 \%$ oleic acid and $10-12 \%$ linoleic acid. Correlating the values obtained in this study with those found in the literature, it is possible to affirm that the verified characteristics are directly related to the fractions obtained from the palm oil, such as stearin and olein. The concentration of oleic acid in palm oil is approximately $36 \%$, with palm olein being $39 \%$, which is a liquid fraction at room temperature (Gee, 2007). According to Table 2, oleic acid is present at 
$37 \%$ of the oil extracted from Type 1 EFBs, which is liquid at room temperature. In addition, Type 1 EFBs also presented approximately $9 \%$ lauric acid, which is the main component $(48 \%)$ of palm kernel oil (Block and Barrera-Arellano, 2013). Therefore, Type 1 EFBs residual oil contains fractions of palm and kernel oils. The residual oil in Type 2 EFBs was solid at room temperature due to the high concentration of saturated fatty acids $(76.5 \%)$, according to the stearin fraction of palm oil (Anton, Bailey, 2005). As palmitic was the predominant fatty acid $(65.9 \%)$ and the lauric acid was not found, it could be inferred that the residual fatty acids of Type 2 EFBs are similar to palm oil only.

Table 3 presents the results on TAG composition of the oil extracted from both EFBs. TAG analyses showed that the predominant TAGs in EFBs were SOM-POP and POO-SLP. Analyzing the Type 2 EFBs, the quantity of myristic acid was very low $(\sim 1 \%)$, while the amount of oleic acid $(\sim 20 \%)$ and palmitic acid $(\sim 65 \%)$ were quite high, so it is assumed that the most probable TAG present is POP. In the case of POO-SLP, in both samples, the probability of having POO is higher than SLP, since the levels of linoleic acid $(\sim 0.8$ and $\sim 3 \%)$ and stearic acid ( $\sim 8$ and $\sim 4 \%$ ) were also very low. According to Chee Man et al., (1999), palm oil has high amounts of POO $(\sim 23 \%)$ and POP $(\sim 29 \%)$ TAGs, which agrees with the data obtained in this work, showing that both EFBs have characteristics of palm oil. However, it can also be seen that in Type 1 EFBs there is lauric acid (LaPLa, $\sim 3 \%$ ), which is characteristic of kernel oil, where lauric acid represents around $50 \%$ of the fatty acid composition. Thus, it was considered the residual oil in Type 2 EFBs which matches palm oil, while Type 1 EFBs contains both palm and kernel oils.

TABLE 3. Triacylglycerol composition of the oils extracted from the EFBs

\begin{tabular}{llcc}
\hline $\begin{array}{l}\text { Carbon } \\
\text { Number }\end{array}$ & Triacylglycerol & $\begin{array}{c}\text { Type 1 } \\
\text { EFBs }^{\mathbf{a}} \text { (\%) }\end{array}$ & $\begin{array}{c}\text { Type 2 } \\
\text { EFBs }^{\mathbf{a}} \text { (\%) }\end{array}$ \\
\hline C40 & LaMM-LaPLa & $3.4 \pm 0.1$ & -- \\
C48 & SLaS-PPP-SMP & $6.1 \pm 0.1$ & -- \\
C48 & MPS-PPP & -- & $16.3 \pm 0.1$ \\
C50 & SOM-POP & $28.1 \pm 0.2$ & $36.7 \pm 0.2$ \\
C50 & SLM-MOO-PLP & $6.3 \pm 0.1$ & $6.1 \pm 0.1$ \\
C52 & POO-SLP & $26.0 \pm 0.5$ & $17.6 \pm 0.1$ \\
C52 & PLO & $6.7 \pm 0.1$ & $4.6 \pm 0.1$ \\
C52 & SOP & -- & $6.5 \pm 0.0$ \\
C54 & SLO-OOO & $4.6 \pm 0.1$ & $3.4 \pm 0.1$ \\
Others $>3 \%$ & & $18.6 \pm 0.6$ & $8.7 \pm 0.6$ \\
\hline
\end{tabular}

${ }^{\mathrm{a}}$ Mean of three replicates \pm Standard Deviation; Values below $0.5 \%$ were omitted from the table. --: not detected; La: Lauric Acid, M: Myristic Acid, P: Palmitic Acid, S: Stearic Acid, O: Oleic Acid.
In relation to the qualitative characterization of the oils and fats, determinations of FFA and peroxides were made. The value for free fatty acids (FFA) obtained for the lipid content extracted from Type 2 EFBs oil was much higher than that from Type 1 EFBs oil, and was, on average, $51.6 \%$ and 9.3\%, respectively (Table 2 ). These values were confirmed by the lipid class analysis, where similar values for monoacylglycerols (MAG) and FFA were obtained (Table 4).

The presence of high amounts of diacylglycerols (DAG), MAG and FFA in the samples indicated a high hydrolysis degree, the action of lipolytic enzymes on the TAG molecules releases DAG, MAG and fatty acids. The high lipolytic activity of palm lipases is already known. Therefore, in the case of an industrial residue, this was clearly expected. Due to the high amount of MAG+FFA in the Type 2 EFBs, it is possible to affirm that it presented a higher degradation level than Type 1 EFBs. This situation can be related to the conditions of palm fruit management as well as the time and conditions of the residue storage, which are not commonly controlled.

Through a visual observation of the residues (Figure 2), it can also be inferred that the processes of extraction of palm oil probably followed different procedures and/or storage times and conditions considering their particularities in terms of composition and appearance. The Type 1 EFBs residual oil

TABLE 4. Glyceridic classes of oils extracted from Types 1 and 2 EFBs

\begin{tabular}{lcc}
\hline Glyceridic classes & $\begin{array}{c}\text { Type 1 } \\
\mathbf{E F B s}^{\mathbf{a}} \mathbf{( \% )}\end{array}$ & $\begin{array}{c}\text { Type 2 } \\
\mathbf{E F B s}^{\mathbf{a}} \mathbf{( \% )}\end{array}$ \\
\hline Triacylglycerols & $74.9 \pm 1.4$ & $45.5 \pm 1.1$ \\
Diacylglycerols & $18.2 \pm 0.6$ & $7.1 \pm 0.3$ \\
Monoacylglycerols+ FFA & $6.8 \pm 1.1$ & $47.2 \pm 1.4$ \\
\hline
\end{tabular}

${ }^{\mathrm{a}}$ Mean of three repetitions \pm standard deviation; FFA $=$ free fatty acids.

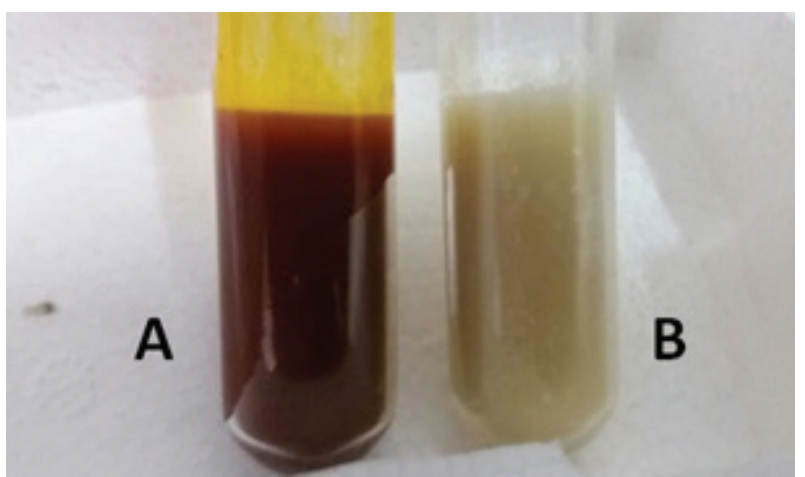

FIgURE 2. Visualization of the residual lipid fractions of Type 1 (A) and Type 2 (B) EFBs. 
showed a red coloration which corresponds to the presence of high amounts of carotenoids; whereas only a white fraction was obtained with EFBs Type 2 , indicating that this residue has a low concentration of carotenoids. This visual difference was confirmed by the analysis of carotenoid concentrations. The amount of carotenoids found in the sample extracted from Type $1 \mathrm{EFBs}$ was $890 \mathrm{mg} \cdot \mathrm{kg}^{-1}$, which was tenfold higher than the content present in the Type 2 EFBs, which was $81 \mathrm{mg} \cdot \mathrm{kg}^{-1}$ (Table 5). These compounds are considered bioactive, because of the connections that are easily oxidized, and for this reason, they presented antioxidant activity (Silva et al., 2010). The low amount of carotenoids in Type 2 EFBs indicates a high level of oxidation of this sample since the antioxidant molecules (carotenoids) were degraded. A similar behavior was noticed for the tocopherol content. The tocopherol known as Vitamin E is a lipid-soluble nutrient with the main function of protecting long-chain polyunsaturated fatty acids from cell membranes and lipoproteins against oxidation (Debier, 2007). According to Wong et al., (1998) the total tocopherol found in crude palm oil was $794 \mathrm{mg} \cdot \mathrm{kg}^{-1}$ and in refined palm oil is $563 \mathrm{mg} \cdot \mathrm{kg}^{-1}$. The lipid fraction extracted from Type 1 EFBs presented $1189 \mathrm{mg} \cdot \mathrm{kg}^{-1}$ of tocopherol, while in the lipid extracted from the Type 2 EFBs the presence of tocopherol was not detected (Table 5). The total tocotrienols in the lipid fraction extracted from Type $1 \mathrm{EFBs}$ was $564 \mathrm{mg} \cdot \mathrm{kg}^{-1}$ (Table 5); the literature shows that palm oil is composed of $188 \mathrm{mg} \cdot \mathrm{kg}^{-1}$ of tocotrienols (Block, Barrera-Arellano, 2013). Table 6 shows the tocopherol and tocotrienol profiles from Type 1 EFBs. Both the tocopherols and tocotrienols were in alpha form.

TABLE 5. Carotenoids, phytosterols, tocopherols and tocotrienols from residual lipids of Type 1 and Type 2 EFBs

\begin{tabular}{lcc}
\hline Compound $(\mathbf{m g} \cdot \mathbf{k g}-\mathbf{1})$ & Type $\mathbf{1 ~ E F B s ~}^{\mathbf{a}}$ & ${\text { Type } \mathbf{2} \mathbf{E F B s}^{\mathbf{a}}}^{\mathbf{2}}$ \\
\hline Carotenoids & $890 \pm 0$ & $81 \pm 5$ \\
Phytosterols & $5271 \pm 150$ & $1102 \pm 13$ \\
Tocopherols & $1189 \pm 5$ & -- \\
Tocotrienols & $564 \pm 1$ & -- \\
\hline
\end{tabular}

${ }^{\mathrm{a}}$ Mean of three repetitions \pm standard deviation; --: not detected

TABLE 6. Tocopherol and Tocotrienol profiles from residual lipids of Type 1 EFBs

\begin{tabular}{lcc}
\hline & Tocopherol $^{\mathbf{a}}\left(\mathbf{m g} \cdot \mathbf{k g}^{-\mathbf{1}}\right)$ & Tocotrienol $^{\mathbf{a}} \mathbf{( \mathbf { m g } \cdot \mathbf { k g } ^ { - 1 } )}$ \\
\hline Alpha & $92.4 \pm 0.4$ & $52.2 \pm 0.7$ \\
Beta & $4.9 \pm 0.2$ & - \\
Gamma & $2.6 \pm 0.2$ & $38.1 \pm 0.6$ \\
Delta & - & $9.5 \pm 0.4$ \\
\hline
\end{tabular}

${ }^{\mathrm{a}}$ Mean of three repetitions \pm standard deviation; -: not detected.
Finally, these oxidation hypotheses were confirmed by the peroxide value. The values obtained for the peroxide value (Table 2) are higher for Type 2 EFBs than for Type 1 EFBs $(67.5 \%$ and $12.4 \%$, respectively). These values confirm the primary oxidation state of oils or fats, which can be influenced by factors such as time and storage conditions after processing (Block, Barrera-Arellano, 2013). It is worth mentioning that the substrate is a residue of palm oil processing, in other words, with raw material that has already undergone several treatments, with later uncontrolled storage of the residue.

The phytosterol content in the lipids from Type 1 EFBs is also higher than the lipid from Type 2 EFBs (Table 5). According to Choo et al., (1996), palm skin has a significant amount of carotenoids ranging from 4000 to $6000 \mathrm{mg} \cdot \mathrm{kg}^{-1}$, vitamin E about 2400$3500 \mathrm{mg} \cdot \mathrm{kg}^{-1}$ and sterols $4500-8500 \mathrm{mg} \cdot \mathrm{kg}^{-1}$. The results of the literature are closer to Type 1 EFBs lipid data, indicating a low degradation level of this residue, unlike Type 2 EFBs.

Table 7 represents the phytosterol profiles of lipids from Type 1 and Type 2 EFBs. It can be observed that the phytosterols found in major quantity in the lipids from both EFBs were $\beta$-sitosterol+sitostanol (61.5 and $63.9 \%)$, followed by campesterol (14.3 and $17.5 \%)$ and stigmasterol (13.4 and 10.3\%), respectively. These phytosterols are generally found in palm oil in greater amounts.

According to the literature, the use of EFBs in fermentation to obtain humic acids has already been studied (Motta and Santana, 2014). The results showed that EFBs are by-products with good potential for the production of humic acids using Trichoderma reesei, both in submerged fermentation and in solid state fermentation. Given such potential, it is suggested that Type 1 EFBs, which have higher levels of lignocellulose content can be used to increase the production of humic acids through the

TABLE 7. Phytosterol profiles from residual lipids of Types 1 and 2 EFBs

\begin{tabular}{lcc}
\hline Phytosterols & Type 1 EFBs $^{\mathbf{a}} \mathbf{( \% )}$ & Type 2 EFBs $^{\mathbf{a}} \mathbf{( \% )}$ \\
\hline Cholesterol & $2.8 \pm 0.0$ & $3.15 \pm 0.0$ \\
Brassicasterol & $0.2 \pm 0.0$ & -- \\
Ergosterol & $4.3 \pm 0.1$ & -- \\
Campesterol & $14.3 \pm 0.0$ & $17.5 \pm 0.1$ \\
Stigmasterol & $13.4 \pm 0.0$ & $10.3 \pm 0.0$ \\
Clerosterol & $1.0 \pm 0.0$ & $2.0 \pm 0.1$ \\
$\beta$ +sitosterol+sitostanol & $61.5 \pm 0.2$ & $63.9 \pm 0.1$ \\
$\Delta 5$-avenasterol & $2.2 \pm 0.0$ & $23.0 \pm 0.0$ \\
$\Delta 5,24$-stigmastadienol & $0.2 \pm 0.0$ & $0.4 \pm 0.2$ \\
$\Delta 7$-stigmatenol & $0.1 \pm 0.0$ & $0.5 \pm 0.1$ \\
$\Delta 7$-Avenasterol & $0.1 \pm 0.1$ & -- \\
\hline
\end{tabular}

${ }^{\mathrm{a}}$ Mean of three replicates \pm standard deviation; --: not detected 
fermentation process. Besides that, the higher levels of phytosterols, carotenoids and tocopherols in Type $1 \mathrm{EFBs}$, could raise the fungus biomass production in the fermentation process. On the other hand, Type 2 EFBs presented higher levels of free fatty acids, which could also be indicated to raise the fungus biomass growth. The presence of free fatty acids eliminates the needed for a TAG hydrolysis step to the fatty acid absorption, facilitating the metabolism of the fungus during the fermentation process to obtain humic acids.

Another alternative for the use of these residues could be the extraction of carotenoids since it was possible to obtain such minor compounds from Type 1 EFBs. The literature already reports a technology in which it is possible to extract carotenoids from pressed palm fiber (PPF), which would be fibers of the palm fruit mesocarp, through the Soxhlet extractor (Cardenas-Toro et al., 2015). In this way, it is evident that it is also possible to use the same technology for EFBs, further optimizing the use of this by-product.

\section{CONCLUSIONS}

The lipids extracted from the two EFBs types had different compositions and characteristics. The contents of cellulose $(\sim 31 \%)$, hemicellulose $(\sim 19 \%)$ and lignin $(\sim 24 \%)$ of Type 1 EFBs were higher than Type 2 EFBs $(\sim 17 \%$ cellulose, $\sim 15 \%$ hemicellulose and $\sim 13 \%$ lignin). The lipid content in Type 1 EFBs presented a fatty acid composition similar to palm oil and palm kernel oil, and a higher amount of carotenoids than the lipids from Type 2 EFBs. In this way, Type 1 EFBs can be used for secondary recovery of the oil to extract the residual carotenoid content. The lipids extracted from Type 2 EFBs presented similar characteristics only to palm oil, and a higher degree of free fatty acids.

The results obtained for the content of lignocellulose showed that EFBs has great potential for application in fermentative processes. It should be emphasized that the content and lipid profile present in the EFBs showed different characteristics which could contribute to the growth of fungus during fermentative processes, as well as the production of humic acids.

\section{ACKNOWLEDGMENT}

The authors are grateful for the support given by The School of Chemical Engineering (FEQ/UNICAMP), Agropalma and cooperative of small palm oil producing industries by supplying the EFBs, and the scholarships from The National Council for Scientific and Technological Development (CNPQ, Brazil) and Coordination for the Improvement of Higher Personnel Education (CAPES, Brazil).

\section{REFERENCES}

AACCI. American Association of Cereal Chemists International. 2010. Approved methods, St. Paul., 11th ed.

Alves SAO, Lemos OF, Santos Filho BG, Silva ALL. 2011. In vitro embryo rescue of interspecific hybrids of oil palm (Elaeis oleifera x Elaeis guineensis). J. Biotechnol. Biodivers. 2, 1-6.

Anton and Bailey. 2005. Bailey's Industrial Oil and Fat Products. $6^{\text {th }}$ ed, vol 2. Edible Oil and Fat Products. ISBN: 978-0-471-38551-6A

AOAC. Official Methods of analysis of AOAC International. 2016. $20^{\text {th }}$ ed.

AOCS. Official Methods and Recommended Practices of the American Oil Chemist's Society. 2009. 6th ed. Campaing.

Block JM, Barrera-Arellano D. 2013. Introduction ala química de lípidos, in Block, JM, Barrera-Arellano, D (Ed.) Temas selectos em aceytes y grasas, 2nd ed, vol 3. Blucher, Inc., pp. 1-37.

Bocchi B. 2008. PhD thesis. Estudo de viabilidade de cogeração de uma unidade de extração de óleo de palma integrada a uma usina de biodiesel. Universidade de São Paulo.

Cardenas-Toro FP, Alcázar-Alay SC, Coutinho JP, Godoy HT, Forster-Carneiro T, Meireles MAA. 2015. Pressurized liquid extraction and low-pressure solvent extraction of carotenoids from pressed palm fiber: Experimental and economical evaluation. Food Bioprod. Proces. 94, 90-100. https://doi.org/10.1016/j.fbp.2015.01.006

Chang SH. 2014. An overview of empty fruit bunch from oil palm as feedstock for bio oil production. Biomass Bioener. 62, 174-181. https://doi.org/10.1016/j.biombioe.2014.01.002

Che man YB, Haryati T, Ghazali HM, Asbi BA. 1999. Composition and thermal profile of crude palm oil and its products. J. Am. Oil Chem. Soc. 76, 237-242. https://doi. org/10.1007/s11746-999-0224-y

Choo YM, Yap SC, Ooi CK, Ma AN, Goh SH, Ong ASH. 1996. Recovered oil from palm-pressed fiber: A good source of natural carotenoids, vitamin E and sterols. J. Am. Oil Chem. Soc. 73, 599-602. https://doi.org/10.1007/BF02518114

Debier C. 2007. Vitamin E During Pre- and Postnatal Periods. Vitamin E, 76, 357-373.

Ferrer A, Filpponen I, Rodríguez A, Laine J, Rojas OJ. 2012. Valorization of residual Empty Palm Fruit Bunch Fibers (EPFBF) by microfluidization: Production of nanofibrillated cellulose and EPFBF nanopaper. Bioresour. Technol. 125, 249-255. https://doi.org/10.1016/j.biortech. 2012.08.108

Gee PT. 2007. Analytical characteristics of crude and refined palm oil and fractions. Euro. J. Lipid Sci. Technol. 109, 373-379. https://doi.org/10.1002/ejlt.200600264

Gioielli LA. 1996. PhD thesis. Misturas Binárias e Ternárias de Gorduras Hidrogenadas na Formulação de Margarinas. Universidade de São Paulo.

Hartman L, Lago BCA. 1973. Rapid preparation of fatty acid methyl esters from lipids. Lab. Practice 22, 475-477.

Hurter R, Byrd MV. 2017. Pulping and bleaching of Malaysian oil palm empty fruit bunches. Tappi J. 16, 361-370.

IUPAC. 1987. Standard Method 2.432. Standard methods for the analysisof oils, fats and derivatives. Determination of tocopherol and tocotrienols in vegetable oils and fats by HPLC. Blackwell Scientific, Oxford, GB.

Lau HLN, Choo YM, Ma AN, Chuah CH. 2008. Selective extraction of palm carotene and vitamin $\mathrm{E}$ from fresh palm-pressed mesocarp fiber (Elaeis guineensis) using supercritical $\mathrm{CO}_{2}$. J. Food Eng. 84, 289-296. https://doi.org/ 10.1016/j.jfoodeng.2007.05.018

Moreda W, Pérez-Camino MC, Cert A. 2003. Improved method for the determination of triacylglycerols in olive oils by high performance liquid chromatography. Grasas Aceites 54, 175-179. https://doi.org/10.3989/gya.2003.v54.i2.262

Motta FL, Santana MHA. 2014. Comparison of humic acids production by Trichoderma viride and Trichoderma reesei using the submerged fermentation of oil palm empty fruit bunch. J. Microbiol. Biotechnol. 13, 1067-1074. https://doi. org/10.5897/AJB2013.13414 
Nazir MS, Wahjoedi BA,Yussof AW, Abdullah MA. 2013. Ecofriendly extraction and characterization of cellulose from oil palm empty fruit bunches. Bioresource 8, 2161-2172.

Porim Test Method. 1995. Kuala Lumpur: Palm Oil Research Institute of Malaysia.

Pujiasih S, Kurnia Masykur A, Kusumaningsih T, Saputra OA. 2018. Silylation and characterization of microcrystalline cellulose isolated from Indonesian native oil palm empty fruit bunch. Carbohyd. Polymers 184, 74-81. https://doi. org/10.1016/j.carbpol.2017.12.060

Rosazley R, Shazana MZ, Izzati MA, Fareezal AW, Rushdan I, Ainun ZMA. 2016. Characterization of Nanofibrillated Cellulose Produced from Oil Palm Empty Fruit Bunch Fibers (OPEFB) Using Ultrasound. Charact. Nanofibrillated Cellulose Prod. 6, 28-35.
Rukmini C. 1994. Red palm oil to combat vitamin A deficiency in developing countries. Food Nutrit. Bull. 15, 1-4.

Santos VS. 2014. PhD thesis. Estruturação de óleo de palma e emulsões utilizando óleo de palma totalmente hidrogenado e lecitina de soja. Universidade Estadual de Campinas, Campinas.

Silva MLC, Costa RS, Santana AS, Koblitz MGB. 2010. Compostos fenólicos, carotenóides e atividade antioxidante em produtos vegetais. Ciências Agrárias 31, 669-682.

Wong ML, Timms RE, Goh EM. 1998. Colorimetric determination of total tocopherols in palm oil, olein and stearin. $J$. Am. Oil Chem. Soc. 65, 258-261. https://doi.org/10.1007/ BF02636412

Yeoh CY, Chin NL, Tan CS. 2011. Co-composting of palm oil mill wastes. J. Food Agric. and Envir. 9, 880-885. 